\title{
Performance Evaluation of Prepackaged-Type Low Shrinkage Surface Preparation Materials Using a VA/E/MMA Terpolymer Powder
}

\author{
Hong, Sun-Hee ${ }^{1} \quad$ Kim, Wan- $\mathrm{Ki}^{2 *}$ \\ Graduate School, Hyupsung University, Bongdam-Eup, Hwaseong, 445-745, Korea ${ }^{1}$ \\ Department of Architectural Engineering, Hyupsung University, Bongdam-Eup, Hwaseong, 445-745, Korea 2
}

\begin{abstract}
Recently, prepackaged-type surface preparation materials using redispersible polymer powders are widely used for interior and exterior finishing in the construction work. The purpose of this study is to evaluate the performance and the quality of prepackaged-type surface preparation materials using a VA/E/MMA terpolymer powder. Surface preparation materials using a VA/E/MMA terpolymer powder were prepared with shrinkage reducing agent contents of $0,4 \%$ and cellulose fiber contents of $0,0.5,1.0 \%$, and tested for drying shrinkage, strengths, adhesion in tension, crack and impact resistance, water absorption, permeability. As a result, prepackaged-type surface preparation materials show outstanding performance depending on the shrinkage reducing agent and cellulose fiber contents.
\end{abstract}

Keywords : terpolymer powder, prepackaged-type, low shrinkage, surface preparation materials

\section{Introduction}

Polymer-modified mortars(PMMs) are widely used in various building constructions such as surface preparation materials, finishing materials, self-leveling materials, patch materials for deteriorated $\mathrm{RC}$ structures, etc[1,2]. This is attributed to the outstanding performance of the PMMs. The improvements from adding polymer modifiers to concrete include increased bond strength, freezing and thawing resistance, abrasion resistance, flexural and tensile strengths, and reduced permeability and elastic modulus[3,4]. Since the development of prepackaged-type products using redispersible polymer powders among others, it is being commonly used till today.

Received : September 16, 2011

Revision received : November 21, 2011

Accepted : November 30, 2011

* Corresponding author : Kim, Wan-Ki

[Tel: 82-31-299-0757, E-mail: wankkim@uhs.ac.kr]

(c)2012 The Korea Institute of Building Construction, All rights reserved.
As a prepackaged product which consists of only powder-type materials, it makes work more efficient[5]. Because the products can be used by just mixing it with water in the construction site[6,7]. It is not only convenient, but gives accuracy of premixing with the cement, aggregates, and other powder components[8, 9]. Also, the use of prepackaged mixture can avoid disposal of buckets, which are normally used to contain the polymer latex. The disposal of these buckets become an environmental concern. So, the use of prepackaged mixture can contribute to decrease of environmental pollution[10]. However, the PMMs using redispersible polymer powders have a defect that drying shrinkage is larger than that of unmodified mortars[3].

Now, commercially available prepackaged-type products using redispersible polymer powders are products using copolymer that two monomers are polymerized. In this paper, developed than that, prepackaged-type surface preparation materials using a new generation of terpolymer powder[11] 
that three monomers(Vinyl Acetate/Ethylene/Methyl Methacrylate) are polymerized are prepared with powdered shrinkage reducing agent for drying shrinkage reducing and cellulose fiber for crack inhibiting and improvement in impact resistance, and tested for various test items to assess the performance.

\section{Materials}

\subsection{Cement}

Ordinary portland cement as specified in $\mathrm{KS} \mathrm{L}$ 5201(Portland Cement)was used as a cement. The chemical compositions and physical properties of the cement are listed in Table 1.

\subsection{Polymeric admixture}

Redispersible polymer powder used as a polymeric admixture was a vinyl acetate-ethylene-methyl methacrylate (VA/E/MMA) terpolymer powder. The properties of the redispersible VA/E/MMA powder are given in Table 2. Before mixing, to control entrained air, polyester-based powdered antifoamer was added to the VA/E/MMA terpolymer powder in a ratio $1 \%$ to the total solids of $\mathrm{VA} / \mathrm{E} / \mathrm{MMA}$ terpolymer powder.

Table 1. Physical properties and chemical compositions of cement

\begin{tabular}{|c|c|c|c|c|c|c|c|c|}
\hline \multirow{2}{*}{$\begin{array}{l}\text { Physical } \\
\text { properties- }\end{array}$} & \multirow{2}{*}{$\begin{array}{l}\text { Density } \\
(20)^{2}, \\
\left.\mathrm{~g} / \mathrm{cm}^{3}\right)\end{array}$} & \multirow{2}{*}{\multicolumn{2}{|c|}{$\begin{array}{c}\text { Blaine's specific } \\
\text { surface area } \\
\left(\mathrm{cm}^{2} / g\right)\end{array}$}} & \multicolumn{2}{|c|}{$\begin{array}{c}\text { Setting time } \\
(\mathrm{h}: \mathrm{min})\end{array}$} & \multicolumn{3}{|c|}{$\begin{array}{c}\text { Compressive } \\
\text { strength (MPa) }\end{array}$} \\
\hline & & & & Initial & Final & & $7 d$ & $28 d$ \\
\hline & 3.14 & & & 4:20 & $6: 50$ & & 8.9 & 36.7 \\
\hline \multirow{2}{*}{$\begin{array}{c}\text { Chemical } \\
\text { compositi } \\
\text { on }(\%)\end{array}$} & $\mathrm{SiO}_{2}$ & $\mathrm{Al}_{2} \mathrm{O}_{3}$ & $\mathrm{Fe}_{2} \mathrm{O}_{3}$ & $\mathrm{Ca}$ & & $\mathrm{MgO}$ & $\mathrm{SO}_{3}$ & $\begin{array}{l}\lg . \\
\text { loss }\end{array}$ \\
\hline & 20.6 & 5.5 & 3.18 & 63.0 & & 3.14 & 2.23 & 1.24 \\
\hline
\end{tabular}

Table 2. Properties of redispersible polymer powder

\begin{tabular}{ccccc}
\hline $\begin{array}{c}\text { Type of } \\
\text { polymer }\end{array}$ & Appearance & $\begin{array}{c}\text { Particle } \\
\text { size }(\mu \mathrm{m})\end{array}$ & $\begin{array}{c}\text { Glass } \\
\text { transition } \\
\text { point }\left({ }^{\circ} \mathrm{C}\right)\end{array}$ & $\begin{array}{c}\mathrm{pH}[10 \% \text { Water } \\
\left.\text { dispersion }\left(20{ }^{\circ} \mathrm{C}\right)\right]\end{array}$ \\
\hline $\mathrm{VA} / \mathrm{E} / \mathrm{MMA}$ & $\begin{array}{c}\text { White } \\
\text { Powder }\end{array}$ & 400 & 12 & 7.0 \\
\hline
\end{tabular}

\subsection{Fine aggregate and filler}

Silica sand(size:0.04 0.60 mm) as specified in KS D 2120(Molding Natural Sand) was used as a fine aggregate, and commercially available ground calcium carbonate(size: less than $2.5 \times 10^{-3} \mathrm{~mm}$ ) was used as a filler. Calcium carbonate powder is an inactive material which is different with other mineral admixtures in the cement paste. It doesn't contribute to strength development. But, it improves the flowability, also has excellent effects on reducing bleeding and heat of hydration. And it has micro-filler effect. So this effect increases the durability of cementitious composites[12].

\subsection{Water-retaining agent}

Hydroxyethyl cellulose(HEC) was used as a waterretaining agent for sufficient hydration reaction and prevention drying out of mortar.

\subsection{Water-reducing agent}

Sulfonated melamine-based high-performance powdered water-reducing agent was used as a water-reducing agent.

\subsection{Shrinkage-reducing agent}

Polyethylene glycol was used as a shrinkage-reducing agent.

\subsection{Crack-inhibiting agent}

To improve crack and impact resistance, cellulose fiber(volume ratio : $0,0.5,1.0 \%$ was used as a crack- inhibiting agent.

\section{Testing procedures}

\subsection{Preparation of binders}

Binders for two types[C-2(finishing thickness : 1 $\sim 3 \mathrm{~mm}$ ), CM-2(finishing thickness : 3 10 mm)] of cementitious surface preparation materials as specified in JIS A 6916(Surface preparation materials 
Table 3. Mix proportions of prepackaged-type surface preparation materials

\begin{tabular}{cccccccccccccc}
\hline \multirow{2}{*}{ Material } & \multicolumn{10}{c}{ Mix proportions $(\mathrm{wt} \%)$} \\
\cline { 2 - 13 } & C-2-A & C-2-B & C-2-C & C-2-D & C-2-E & C-2-F & CM-2-A & CM-2-B & CM-2-C & CM-2-D & CM-2-E & CM-2-F \\
\hline Ordinary portland cement & 56.6 & 56.3 & 56.2 & 55.3 & 55.1 & 54.9 & 34.1 & 33.9 & 33.8 & 33.6 & 33.5 & 33.3 \\
Silica sand & 22.5 & 22.4 & 22.4 & 22.0 & 21.9 & 21.9 & 62.5 & 62.3 & 61.9 & 61.6 & 61.4 & 61.2 \\
Calcium carbonate & 14.2 & 14.2 & 14.2 & 14.2 & 14.2 & 14.2 & - & - & - & - & - & - & 3.4 \\
Redispersible polymer powder & 5.6 & 5.6 & 5.6 & 5.5 & 5.5 & 5.5 & 3.4 & 3.4 & 3.4 & 3.4 & 3.4 & 3.3 \\
Antifoamer & 0.056 & 0.056 & 0.056 & 0.055 & 0.055 & 0.055 & 0.034 & 0.034 & 0.034 & 0.034 & 0.034 & 0.034 \\
Water-reducing agent & 0.56 & 0.56 & 0.56 & 0.55 & 0.55 & 0.55 & - & - & - & - & - & - \\
Water-retaining agent & 0.5 & 0.5 & 0.5 & 0.49 & 0.49 & 0.49 & 0.34 & 0.34 & 0.34 & 0.34 & 0.34 & 0.34 \\
Shrinkage-reducing agent & 0 & 0 & 0 & 2.21 & 2.20 & 2.20 & 0 & 0 & 0 & 1.34 & 1.34 & 1.34 \\
Crack inhibiting agent & 0 & 0.29 & 0.59 & 0 & 0.3 & 0.6 & 0 & 0.39 & 0.78 & 0 & 0.39 & 0.79 \\
Water-cement ratio(\%) & 39 & 40 & 43 & 40 & 41 & 44 & 62 & 67 & 72 & 63 & 69 & 76 \\
\hline
\end{tabular}

for finishing) were previously prepared with the mix proportions given in Table 3.

\subsection{Preparation of specimens}

According to KS F 2476(Test Method for PolymerModified Mortar), PMMs were mixed and their flows were adjusted to be constant at $135 \pm 5 \mathrm{~mm}(\mathrm{C}-2)$ and $160 \pm 5 \mathrm{~mm}(\mathrm{CM}-2)$. After that, beam specimens $40 \times 40 \times 160 \mathrm{~mm}$ for compressive and flexural strengths were molded and moisture cured at $20 \pm 2$ ${ }^{\circ} \mathrm{C}$ and $90 \pm 10 \%(\mathrm{RH})$ for 2 days. The specimens were then dry cured at $20 \pm 2{ }^{\circ} \mathrm{C}$ and $60 \pm 10 \%(\mathrm{RH})$ for 26days.

Beam specimens for drying shrinkage test were molded, and moisture cured at $20 \pm 2{ }^{\circ} \mathrm{C}$ and $90 \pm 10$ $\%(\mathrm{RH})$ for 2days. Specimens for crack and impact resistance test were molded by using frame of 3 $\mathrm{mm}(\mathrm{C}-2)$ and $10 \mathrm{~mm}(\mathrm{CM}-2)$ thickeness made with PVC on the concrete board $300 \times 300 \times 60 \mathrm{~mm}$. Before placing mortar, bonding surfaces of concrete substrates were treated with No.150 abrasive paper, and then wetted with water. The molded specimens were moisture cured at $20 \pm 2{ }^{\circ} \mathrm{C}$ and $90 \pm 10 \%(\mathrm{RH})$ for 24hours, then dry cured at $20 \pm 2{ }^{\circ} \mathrm{C}$ and $60 \pm 10$ $\%(\mathrm{RH})$ for 6days. Specimens for adhesion in tension test were molded by the same method, and moisture cured at $20 \pm 2{ }^{\circ} \mathrm{C}$ and $90 \pm 10 \%(\mathrm{RH})$ for 2 days, then dry cured at $20 \pm 2{ }^{\circ} \mathrm{C}$ and $60 \pm 10 \%(\mathrm{RH})$ for 12days for $\mathrm{C}-2$, and moisture cured at $20 \pm 2{ }^{\circ} \mathrm{C}$ and $90 \pm 10$ $\%(\mathrm{RH})$ for 2 days. The specimens were then dry cured at $20 \pm 2{ }^{\circ} \mathrm{C}$ and $60 \pm 10 \%(\mathrm{RH})$ for 26days for $\mathrm{CM}-2$.

Specimens for water absorption test were prepared as follows : ordinary-cement mortar was mixed with a mass ratio of cement standard sand $1: 2$ and a water-cement ratio of 0.65 . Mortar substrates $70 \times 70 \times 20 \mathrm{~mm}$ were molded, and moisture cured at $20 \pm 2{ }^{\circ} \mathrm{C}$ and $90 \pm 10 \%(\mathrm{RH})$ for 24hours, then water cured at $20 \pm 2{ }^{\circ} \mathrm{C}$ for 6days, and dry cured at $20 \pm 2$ ${ }^{\circ} \mathrm{C}$ and $60 \pm 10 \%(\mathrm{RH})$ for 7 days. The bonding surfaces of the mortar substrates were treated with the No.150 abrasive papers, and wetted with water. PMMs were molded in the thickness of $2 \mathrm{~mm}$ on the water-wetted mortar substrates, and moisture cured at $20 \pm 2{ }^{\circ} \mathrm{C}$ and $90 \pm 10 \%(\mathrm{RH})$ for 2days, then dry cured at $20 \pm 2{ }^{\circ} \mathrm{C}$ and $60 \pm 10 \%(\mathrm{RH})$ for 5days. Finally, specimens $200 \times 200 \times 10 \mathrm{~mm}$ for water permeability test were molded and moisture cured at $20 \pm 2{ }^{\circ} \mathrm{C}$ and $90 \pm 10 \%(\mathrm{RH})$ for 24hours, then dry cured at $20 \pm 2{ }^{\circ} \mathrm{C}$ and $60 \pm 10 \%(\mathrm{RH})$ for 27 days.

\subsection{Test of fresh polymer-modified mortars}

Flow and unit weight of fresh PMMs were 
measured by the procedures specified in $\mathrm{KS} F$ 2476(Test Method for Polymer-Modified Mortar), consistency change test was conducted in accordance with KS F 4716 (Cement Filling Compound for Surface Preparation).

\subsection{Drying shrinkage test}

After moisture curing at $20 \pm 2{ }^{\circ} \mathrm{C}$ and $90 \pm 10$ $\%(\mathrm{RH})$ for 2days, original length of beam specimens was measured, then the specimens were dried at 20 ${ }^{\circ} \mathrm{C}$ and $60 \%(\mathrm{RH})$ for $28 \mathrm{~d}$. And their drying shrinkage was measured in accordance with KS F 2424(Test Method for Length Change of Mortar and Concrete).

\subsection{Crack and impact resistance test}

As shown in Figure 1, crack resistance test was conducted in accordance with JIS A 6916. The mortar surface was visually checked for crack occurrence on the 7-day. After that, impact resistance was tested by impacting the surface with steel ball in accordance with JIS A 6916.

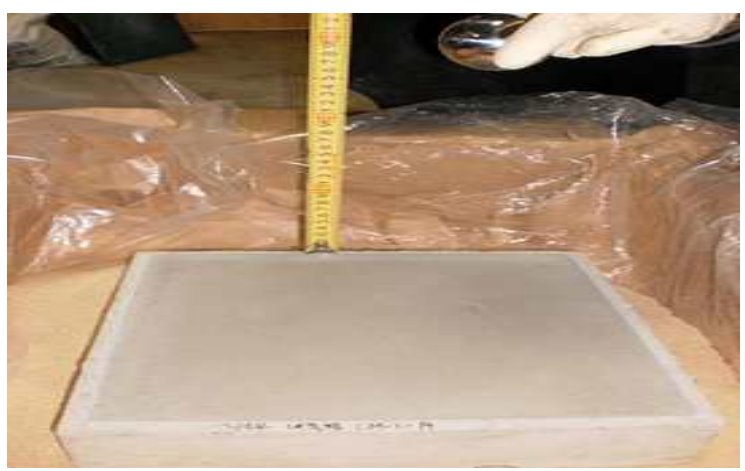

Figure 1. Impact test setup

\subsection{Compressive and flexural strength tests}

Beam specimens were tested for compressive and flexural strengths in accordance with KS F 2476.

\subsection{Adhesion test}

As shown in Figure 2, specimens cut in the size of $40 \times 40 \mathrm{~mm}$ were tested for adhesion in tension to concrete substrates in accordance with JIS A 6916.

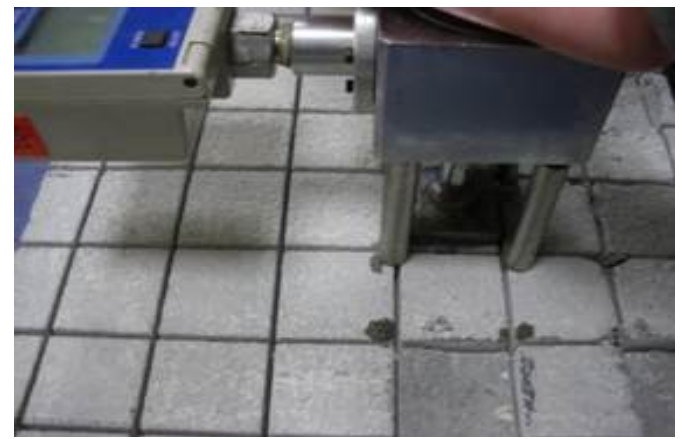

Figure 2. Adhesion test setup

\subsection{Water permeation test}

According to JIS A 6916, 28-day cured specimens were immersed for 24hours, then the specimens were set up with pipette and funnel that the bottom of the specimens were in contact with water as shown in Figure 3.

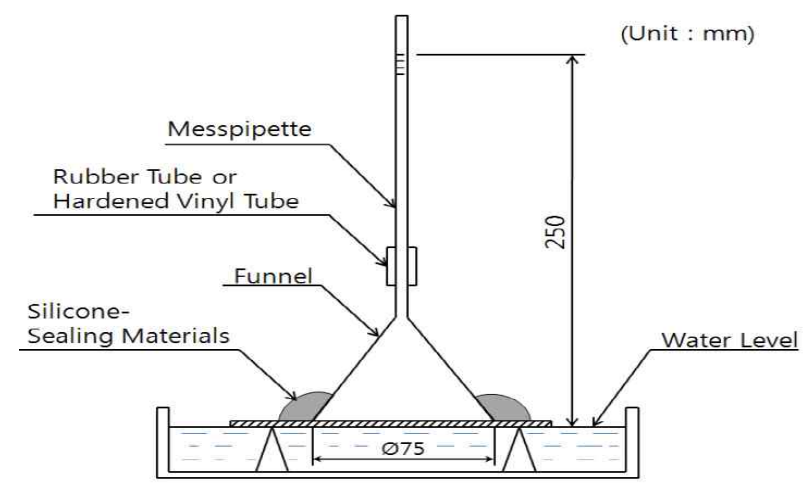

Figure 3. Water permeation test setup

\subsection{Water absorption test}

According to JIS A 6916, specimen was set up that surface preparation material was toward the bottom as shown in Figure 4, and immersed to a depth of $15 \mathrm{~mm}$. After 10minutes, water absorption was measured.

(Unit : $\mathrm{mm}$ )

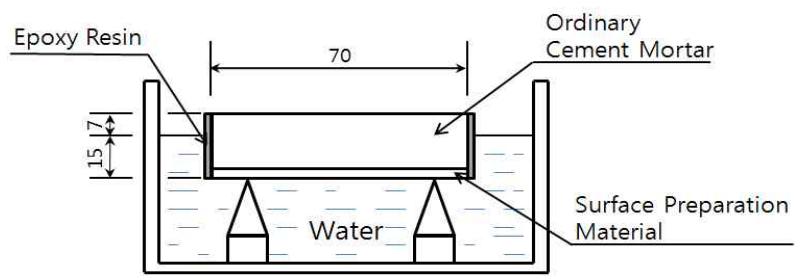

Figure 4. Water absorption test setup 


\section{Test results and discussions}

Table 4 shows the test results of prepackagedtype low shrinkage surface preparation materials using VA/E/MMA terpolymer powder. Overall, water-cement ratio and consistency change of surface preparation materials increase with an increase in the cellulose fiber and shrinkage reducing agent content. However, the consistency change of surface preparation materials is considered not to be a problem in workability or other performance during real work, since the change is within quality requirements. Meanwhile, surface preparation materials both $\mathrm{C}-2$ and $\mathrm{CM}-2$ give high performance in the crack and impact resistance test. No cracks and delamination were observed.

Figure 5 shows the dry curing period vs. drying shrinkage of prepackaged-type surface preparation materials. Drying shrinkage of both $\mathrm{C}-2$ and $\mathrm{CM}-2$ are inclined to increase with dry curing period, and the rate of increase is inclined to decrease with dry curing period. The changes of $\mathrm{C}-2$ are higher than that of $\mathrm{CM}-2$. This tendency is attributed to relatively high unit weight of cement of $\mathrm{C}-2$ than that of $\mathrm{CM}-2$. Also, because of the more compact pore structure of $\mathrm{C}-2$ by micro-filler effect of calcium carbonate used as a filler, increased capillary tension causes increasing drying shrinkage when water evaporates $[13,14]$.
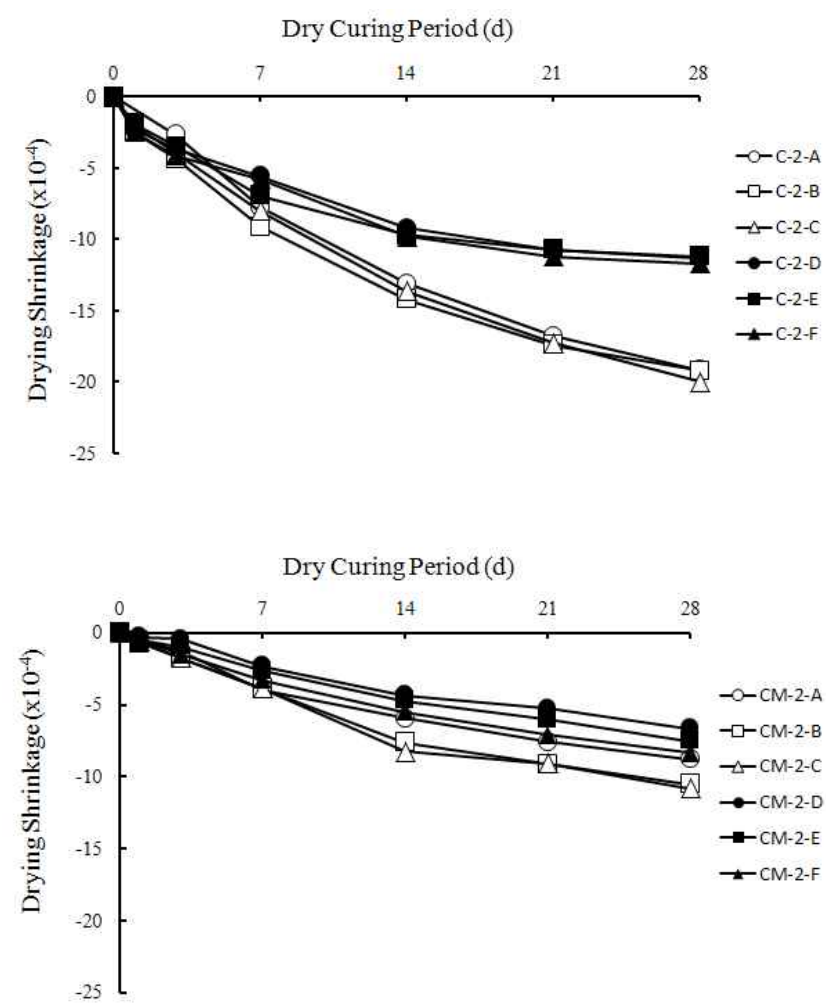

Figure 5. Dry curing period vs. drying shrinkage of prepackaged-type surface preparation materials

Table 4. Test results of prepackaged-type surface preparation

\begin{tabular}{|c|c|c|c|c|c|c|c|c|c|c|c|c|c|c|}
\hline \multirow{2}{*}{ Test Items } & \multicolumn{2}{|c|}{ Quality requirements } & \multicolumn{12}{|c|}{ Surface preparation materials } \\
\hline & C-2 & $\mathrm{CM}-2$ & $C-2-A$ & $C-2-B$ & $C-2-C$ & $C-2-D$ & $C-2-E$ & $C-2 F$ & CM-2-A & CM-2-B & CM-2-C & CM-2-D & CM-2-E & al-2-F \\
\hline $\begin{array}{c}\text { Flow } \\
(\mathrm{mm})\end{array}$ & \multicolumn{2}{|r|}{-} & 139 & 140 & 138 & 136 & 133 & 138 & 161 & 158 & 159 & 164 & 162 & 163 \\
\hline Consistency change & \multicolumn{2}{|c|}{ Less than 15} & 3.3 & 3.8 & 7.9 & 9.5 & 10 & 11 & 1.3 & 1.9 & 2.5 & 2.1 & 2.1 & 2.9 \\
\hline $\begin{array}{l}\text { Compressive strength } \\
(\mathrm{MPa})\end{array}$ & - & $\begin{array}{c}\text { More } \\
\text { than } 10\end{array}$ & - & - & - & - & - & - & 29.5 & 26.5 & 21.4 & 26.7 & 22.2 & 18.3 \\
\hline $\begin{array}{l}\text { Flexural strength } \\
(\mathrm{MPa})\end{array}$ & - & $\begin{array}{l}\text { More } \\
\text { than } 5\end{array}$ & - & - & - & - & - & - & 8.2 & 8.6 & 9.2 & 8.1 & 8.0 & 8.6 \\
\hline Adhesion in tension & \multicolumn{2}{|c|}{ More than 1} & 1.7 & 1.7 & 1.9 & 2.7 & 1.6 & 2.0 & 2.7 & 2.8 & 2.9 & 3.1 & 1.7 & 2.7 \\
\hline Water absorption & $\begin{array}{l}\text { Less } \\
\text { than } 1\end{array}$ & $\begin{array}{l}\text { Less } \\
\text { than } 2\end{array}$ & 0.67 & 0.75 & 0.87 & 0.81 & 0.83 & 0.92 & 0.08 & 1.19 & 1.37 & 1.11 & 1.24 & 1.6 \\
\hline Water permeation & - & $\begin{array}{l}\text { Less } \\
\text { than } 0.5\end{array}$ & - & - & - & - & - & - & 0.1 & 0.15 & 0.15 & 0.15 & 0.21 & 0.25 \\
\hline Drying shrinkage & - & $\begin{array}{l}\text { Less } \\
\text { than } 0.150\end{array}$ & 0.192 & 0.192 & 0.200 & 0.113 & 0.112 & 0.117 & 0.088 & 0.105 & 0.108 & 0.066 & 0.075 & 0.084 \\
\hline Crack resistance & \multicolumn{2}{|c|}{ No cracking } & \multicolumn{5}{|c|}{ No cracking } & \multicolumn{7}{|c|}{ No cracking } \\
\hline Impact resistance & \multicolumn{2}{|c|}{$\begin{array}{l}\text { No cracking and } \\
\text { delamination }\end{array}$} & \multicolumn{5}{|c|}{ No cracking and delamination } & \multicolumn{7}{|c|}{ No cracking and delamination } \\
\hline
\end{tabular}


Figure 6 illustrates the cellulose fiber content vs. 28-d drying shrinkage of prepackaged-type surface preparation materials.

The drying shrinkage of both $\mathrm{C}-2$ and $\mathrm{CM}-2$ are inclined to increase with cellulose fiber content. It is commonly known that addition of cellulose fiber is effective in reducing drying shrinkage.

However, the range of flow is fixed item in this study and water-cement ratio is controlled for the proper workability. On this account, addition of cellulose fiber causes increasing of water-cement ratio. This increasing of water-cement ratio brings about increasing amount of water evaporation. Therefore, it can' $t$ say that addition of cellulose fiber decreases drying shrinkage. But the influence of cellulose fiber content on the drying shrinkage is not so high, and the drying shrinkage decreases with the addition of shrinkage reducing agent.

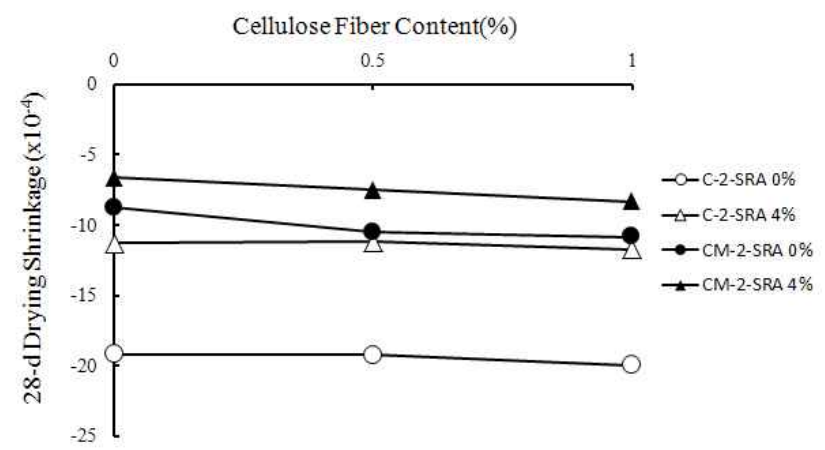

Figure 6. Cellulose fiber content vs. 28-d drying shrinkage of prepackaged-type surface preparation materials

Figure 7 exhibits cellulose fiber content vs. strengths of prepackaged-type surface preparation materials $(\mathrm{CM}-2)$. The compressive strength decreases with increasing the cellulose fiber and shrinkage reducing agent content. And flexural strength also slightly decreases with an increase in the shrinkage reducing agent content. However, this is improved by increasing cellulose fiber content.
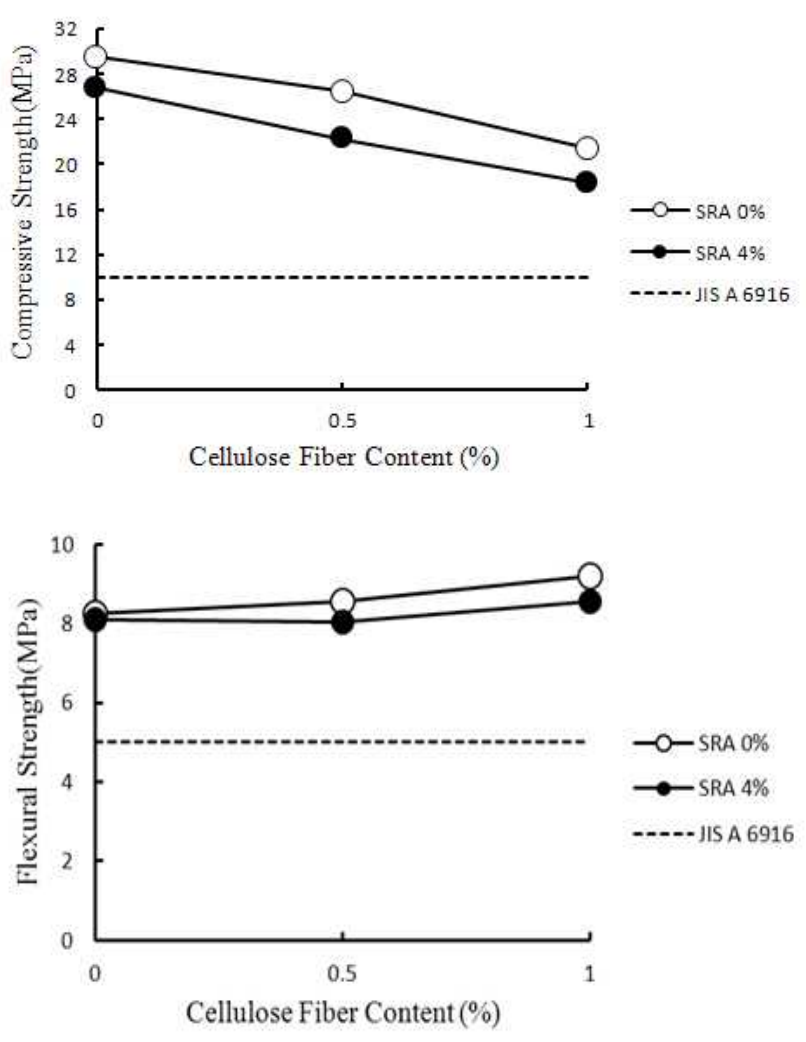

Figure 7. Cellulose fiber content vs. strengths of prepackagedtype surface preparation materials $(\mathrm{CM}-2)$

Figure 8 represents cellulose fiber content vs. the adhesion in tension of prepackaged-type surface preparation materials. The adhesion in tension of both $\mathrm{C}-2$ and $\mathrm{CM}-2$ increases with increasing shrinkage reducing agent content at a cellulose fiber content of $0 \%$. However, adhesion in tension of surface preparation materials with shrinkage reducing agent tends to decrease with increasing cellulose fiber content.

Figure 9 shows cellulose fiber content vs. water absorption of prepackaged-type surface preparation materials. The water absorption of both $\mathrm{C}-2$ and CM-2 increase with increasing cellulose fiber and shrinkage reducing agent content. This tendency is caused by increasing water-cement ratio by use of cellulose fiber and shrinkage reducing agent. Because the increase of water-cement ratio affects on the pore structure of cement matrix[15]. 

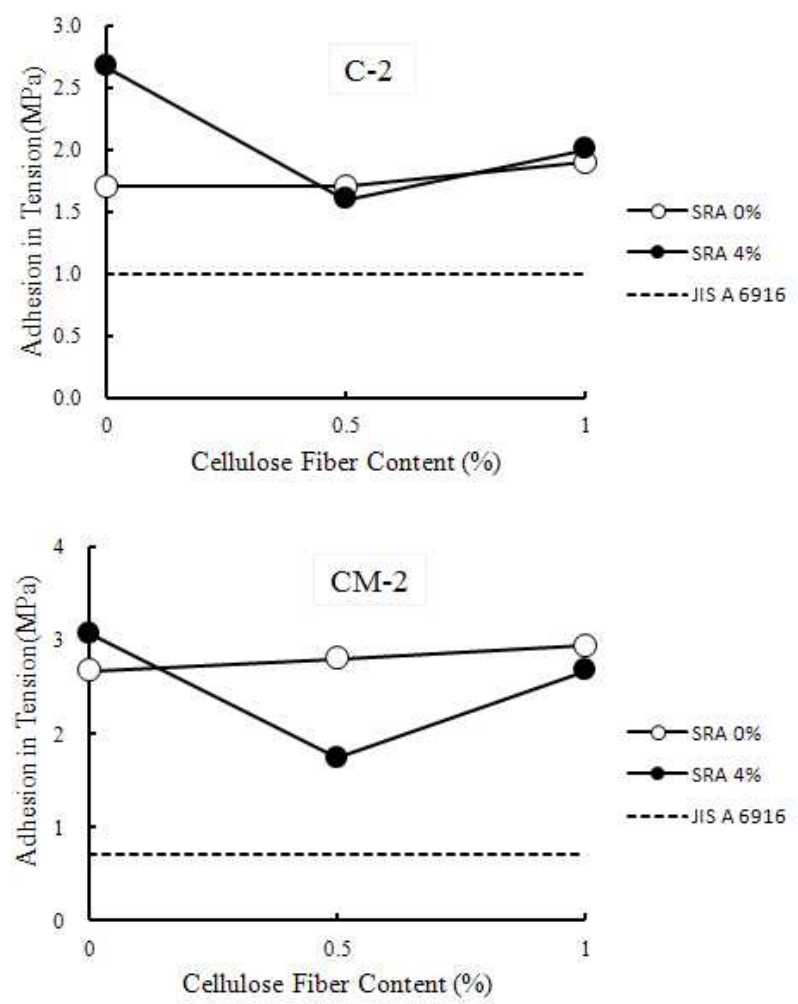

Figure 8. Cellulose fiber content vs. adhesion in tension of prepackaged-type surface preparation materials
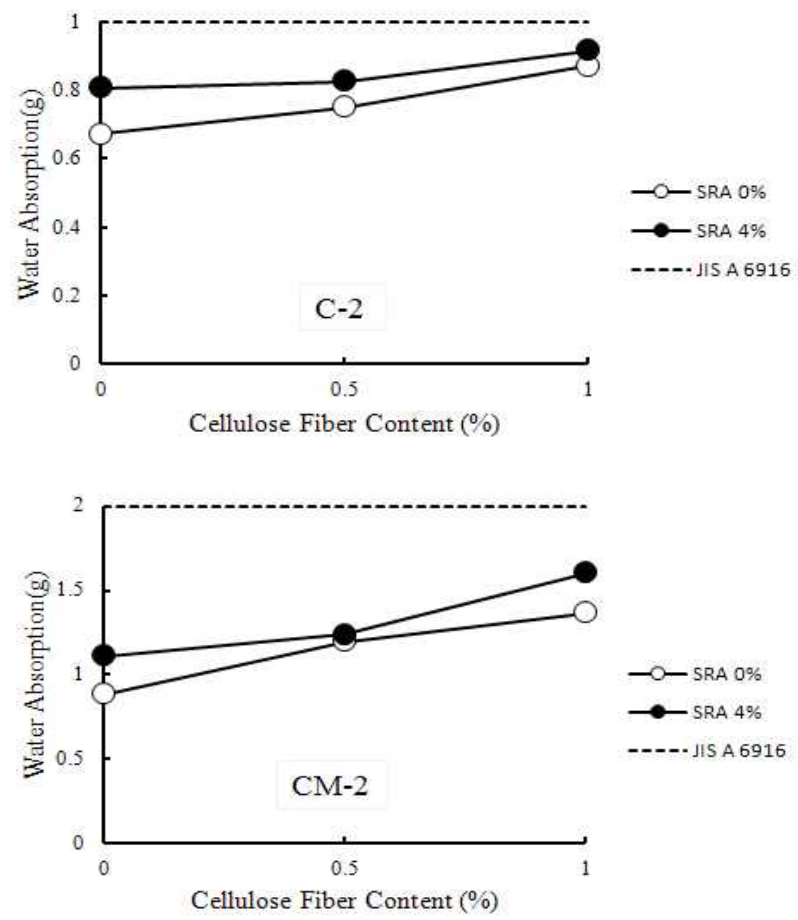

Figure 9. Cellulose fiber content vs. water absorption of prepackaged-type surface preparation materials
Figure 10 illustrates cellulose fiber content vs. water permeation of prepackaged-type surface preparation materials(CM-2). The amount of water permeation of CM-2 increases with increasing cellulose fiber and shrinkage reducing agent content. The tendency is similar to that of water absorption. This is also explained by the reason that the use of cellulose fiber and shrinkage reducing agent cause an increase in water-cement ratio, and it makes porous structure by the evaporation of moisture in the hardened PMMs.

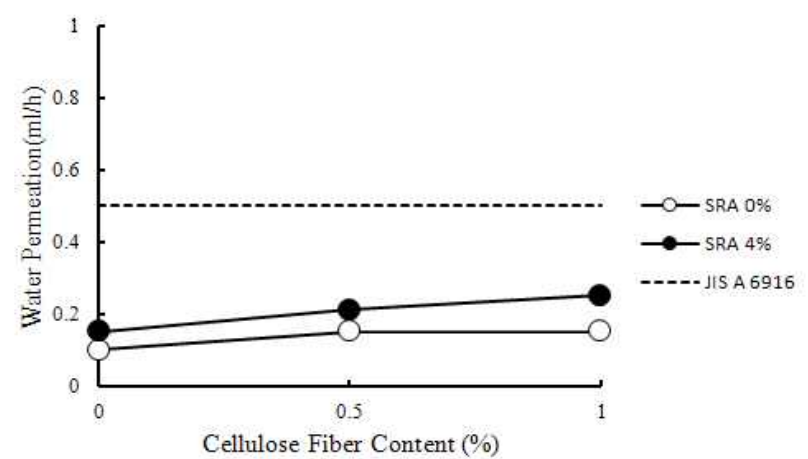

Figure 10. Cellulose fiber content vs. water permeation of prepackaged-type surface preparation materials

\section{Conclusions}

In this study, performance of prepackaged-type low shrinkage surface preparation materials using a VA/E/MMA terpolymer powder was evaluated, and the conclusions obtained from the test results are summarized as follows:

1) Water-cement ratio and consistency changes of surface preparation materials are increased with increasing cellulose fiber and shrinkage reducing agent. However, all of consistency changes of both $\mathrm{C}-2$ and $\mathrm{CM}-2$ meet the quality requirements.

2) Drying shrinkage of surface preparation materials are considerably affected by shrinkage reducing agent rather than cellulose fiber, and it causes a decrease in the drying shrinkage. 
3) Compressive strength of surface preparation materials decreases with increasing shrinkage reducing agent and cellulose fiber content. And flexural strength increases with an increase in the cellulose fiber content, decreases with using shrinkage reducing agent. But all of them meet the quality requirements.

4) Regardless of the shrinkage reducing agent and cellulose fiber content, adhesion in tension of surface preparation materials is $1.7 \mathrm{MPa}$ or more, and meets the quality requirements $(1.0$ MPa or more).

5) In general, water absorption and water permeation of surface preparation materials are slightly increased with increasing cellulose fiber and shrinkage reducing agent content. However, they also meet the quality requirements by standard.

6) As surface preparation materials for various finishing materials including tiles, the performance of prepackaged-type low shrinkage surface preparation materials using a VA/E/MMA terpolymer powder is evaluated in this study, and the surface preparation materials using a VA/E/MMA terpolymer powder give outstanding performance meeting quality requirements by standard in all the test items. As a result, it is expected that prepackaged-type products can be applied as custom-made products by use development based on the result from this study.

\section{References}

1. Ohama Y, Ibe H, Mine H, Kato K. Cement Mortars Modified by SB Latexes with Variable Bound Styrene. Rubber Chemistry and Technology. 1964 July/September; 37(3):758-69.

2. Czarnecki L. Concrete-Polymer Composites: Overview. In: Lakshmanan N, Vaidyanathan CV, Ohama Y, Neelamegam M, editors. 5th Asian Symposium on Polymers in Concrete. Proceedings of the Fifth Asian Symposium on Polymers in Concrete; 2006 September 11-12; Structural Engineering
Research Centre CSIR Campus, Chennai, India. Chennai (India): Allied Publishers; 2006. p. 87-104.

3. Ohama Y, Demura K, Kim WK. Properties of Polymer-Modified Mortars Using Redispersible Polymer Powders. In: Yeon KS, Choi JD, editors. The First East Asia Symposium on Polymers in Concrete. Proceedings of the First East Asia Symposium on Polymers in Concrete; 1994 May 2-3; Kangwon National University, Chuncheon, Korea. Chuncheon (Korea): Kangwon National University; 1994. p. 81-90.

4. Ohama Y. Handbook of Polymer-Modified Concrete and Mortars. 1st ed. New Jersey: Noyes Publications; c1995. 236 p.

5. Walters DG. VAE Redispersible-Powder Hydraulic-Cement Admixtures. Concrete International. 1992 April;14(4):30-4.

6. Hackel E, Beng P, Horler S. The use of redispersible polymer powders in concrete restoration. In: Stynes BW, editor. The production, performance \& potential of polymers in concrete. Proceedings of the 5th International Congress on Polymers in Concrete; 1987 September 22-24; Brighton Polytechnic, Brighton, UK. Brighton (UK): Brighton Polytechnic; 1987. p. 305-8.

7. Afridi MUK, Ohama Y, Demura K, Iqbal MZ. Development of Polymer Films by the Coalescence of Polymer Particles in Powdered and Aqueous Polymer-Modified Mortars. Cement and Concrete Research. 2003 November;33(11):1715-21.

8. Grosskurth KP, Konietzko A. Structural models of thermoplastic polymer additives in cement-bound construction materials. Kunststoffe Plast Europe. 1989; $79(5): 23-6$.

9. Saand A, Ismail M, Sumadi SR. Influence of Prepackaged Polymer-Modified Mortar as a Modifier on Strength of Concrete. Journal of Applied Sciences. 2007 ;7(24):4023-27.

10. ACI Committee 548.3R-09. Report on Polymer-Modified Concrete. 1st ed. Farmington Hills (MI): American Concrete Institute; c2009. 40 p.

11. Kim WK. Properties of Polymer-Modified Mortars Using a VA/E/MMA Terpolymer Powder. Journal of the Architectural Institute of Korea. 2010 July;26(7):111-18.

12. Jung HS, Lee ST, Kim JP, Park KP, Kim SS. Evaluation of Durability of Cement Matrix Replaced with Ground Calcium Carbonate. Journal of the Korean Institue of Resources Recycling. 2006 June;15(3):74-80.

13. Smith RH, Mills RH. Variations in the Shrinkage of Concrete Resulting from the Use of Additives. Proceedings 
of the RILEM/CEMBUREAU International Coloquium on the Shrinkage of Hydraulic Concretes; 1968 March; Instituto Eduardo Torroja, Madrid, Spain. Madrid (Spain): [publisher unknown]; 1968. P. II-G.0-II-G.15.

14. Bentz DP, Aitcin PC. The Hidden Meaning of Water-Cement Ratio. Concrete International. 2008 May; 30(5):51-4.

15. Halamickova P, Detwiler RJ. Water Permeability and Chloride Ion Diffusion in Portland Cement Mortars: Relationship to Sand Conctent and Critical Pore Diameter. Cement and Concrete Research. 1995 May;25(4):790-802. 